\title{
EXPERIENCES WITH THE IRON CURTAIN PRESS
}

\author{
BY PAUL W. MASSING
}

Paul W. Massing, German-born, has a Ph.D. from the University of Frankfurt-Main; he is a member of the Department of Sociology at Rutgers. In 1949, Harper's published his study on the history of political anti-Semitism in Imperial Germany. Besides teaching, he supervises the department's study of Soviet reactions to the broadcasts of the "Voice of America."

$\mathrm{O}$

$\mathrm{NE}$ of the research projects which the Rutgers Department of Sociology is currently conducting calls for a continuous analysis of Iron Curtain reactions to the broadcasts of the Voice of America. The source material studied is a specified sample of Soviet and Satellite newspapers, periodicals, and radio broadcasts. All Iron Curtain publications involved will eventually be incorporated into the Rutgers University Library.

The press sample consists of seven Soviet dailies, eight Soviet journals, and twenty-five Satellite publications, dailies and periodicals. Among the Soviet publications are Pravda and Izvestia, the central organs of the Bolshevik Party and of the Soviet government, respectively; Komsomolskaya Pravda, the paper of the Communist youth organization; Trud, the organ of the All-Union Central Council of Trade Unions; For a Lasting Peace, For a People's Democracy, the Russian edition of the multi-language paper of the Cominform. Among them also is The Bolshevik, the most important theoretical and political journal of the Central Committee of the Bolshevik Party; the illustrated Ogonyok (the Little Flame) and the satirical Krokodil, both published by Pravda.

The Satellite sample consists of publications from Albania, Bulgaria, Czechoslovakia, Hungary, Poland, Rumania, and Eastern Germany. For each of these countries, the central organ of the Communist Party is included, at least one publication addressed to the literary and artistic élite, and a daily or magazine of more popular appeal. The project has been going for almost a year, and is just now in the process of being extended for at least one more year.

When we first budgeted the study, we estimated subscription prices for all publications, Soviet and Satellite, on the basis of the 
official Soviet price list. A good many of the Soviet papers and journals can be subscribed to for air mail delivery at twice the cost of ordinary mail. Since it takes about as many weeks for regular mail to arrive from Eastern Europe as it does days for air mail delivery, we ordered most of the Satellite papers to be sent by air also. We soon learned that when it comes to subscribing to publications, the Iron Curtain is by no means a well coordinated entity. There is an extraordinary variety in the treatment of foreign subscribers from one country to another. The Soviets have been by far the most businesslike in their dealings with us. We paid for airmail and their publications arrive by air quite regularly and relatively quickly. With respect to the Satellites, the situation proved to be outright chaotic. Some never answered our letters. Some accepted our international money orders without feeling obliged to send us something in return. One country in particular defied all rules of normal business intercourse, and just ignored our pleas. Then through one of our scouts we heard of the strange plight of a person in New York, a native of the country in question. The unfortunate man was near insanity because every day the mail would bring him the two most important newspapers of his native country free of charge. When our scout diplomatically approached him with the suggestion that we buy the papers from him after he had read them, he fairly thrust an unwrapped bundle of copies into her hands, more than eager to get rid of them. For a couple of weeks our problem seemed solved. Then the papers suddenly stopped arriving.

The regular subscription price to the Satellite daily may amount to ten dollars a year, but to receive it by air mail would cost an additional hundred dollars. In some cases the papers cannot be subscribed to by private persons; in others only by private persons. Sometimes a country will send only metropolitan papers and exclude all regional or professional papers from the list of those which may be exported. Papers of some countries cannot be officially subscribed to at all but are available on the "black market." At least one accredited agency wrote us that it is the sole foreign distributor and accepted payment for a year's subscription. This happened four months ago, and was the last we have heard from them. In the meantime, we have the papers read in one of the small libraries organized by a group of refugees from that country. How they get them is a jealously guarded secret. 
This state of affairs reminds me of an experience I had in Moscow in 1930. One day a librarian of the International Agrarian Institute where I worked was arrested. When I inquired into the reason, I was told that he had been dealing on the black market. Eventually I found out that the man had not speculated in eggs, steel or oil, but in foreign newspapers. He would take the fashion section out of the Sunday edition of a German or French paper, for which Moscow ladies were willing to pay fabulous prices. Now New York has a black market in Iron Curtain publications although not for the sake of Albanian or Bulgarian haute coûture.

It seems justified to say that the greater the political insecurity or instability of a Satellite regime, the more difficult it is to establish any kind of normal business relations. The personal risks for people in charge of dealing with the free world is very great. Contacts with foreigners even through "channels" may easily become fatal in the continuous intrigues of the police state where guilt by association is an established principle, and association with "Wall Street" and "US warmongers" tantamount to high treason. The less settled the new regimes, the less institutionalized the relations with "the enemy," the greater the dangers involved. Under such circumstances, doing nothing is the wisest course to take.

The reader who has never seen a Soviet or Satellite newspaper will first be struck by certain characteristics. The papers are all very small as compared to the American press. Pravda, for instance, politically probably the most important of all Iron Curtain dailies, appears most of the time with four, occasionally with six pages (up to I 949 it had eight pages). The newsprint usually is of poorer quality than that used for the Western press. Conspicuous is the almost total absence of advertising. The content throughout would impress most American readers as unalleviated boredom, the style as extremely stereotyped. There are no gossip columns, no stories of divorce, murder, rape, or gambling. The distinction between news and interpretation of the news seems non-existent, particularly in political matters. However, just as an experienced technician can draw certain conclusions from the characteristics of a piece of machinery as to the prevailing standards of workmanship, science and technology under which it had been produced, an experienced reader of Iron Curtain publications can learn a great deal about the countries of origin.

A fundamental distinction between the Iron Curtain and the west- 
ern press is the difference in functions. The Iron Curtain press does not serve to inform and entertain but to indoctrinate and direct. It is a major tool of political organization. Stereotypy and repetition are consciously used to create and reinforce desired patterns of thought and emotions. Nothing is left to chance. The reader is presented with the right answers to all questions. So far, however, there are considerable differences in the degree which this manipulation of the reader has reached in the USSR and her Satellites. The reader of the Soviet press has been thoroughly conditioned by unchallenged exposure to the controlled media; but in the Satellite countries, the old social structures are either not yet completely destroyed, or at least the memories of the past are still strong enough to make a more flexible, a more realistic and sophisticated approach necessary. It is entirely impossible to find in the Soviet press an admission, let us say, that the standard of living is higher in the United States than in the USSR; in the Polish papers on the other hand, there appear articles dealing, for instance, with the meat shortage which has been plaguing the government ever since the outbreak of the Korean War, and which according to the governmental press was caused by the peasants slaughtering pigs and cattle in anticipation of a general war.

Needless to say, the process of equalization among the Iron Curtain media is relentlessly going on and has succeeded in putting out a product of basic uniformity. This uniformity does not exclude specialization. Style and content of the papers and periodicals show that they are written for specific groups of the population, the political élite, the peasantry, professional groups, youth, or women. Since these publications do not grow and decline according to their popularity but are maintained or discontinued by dictum of the government, their circulation figures are highly informative. But here again we encounter one of the mysteries of Communist regimes. Circulation figures are given for the periodicals but not for the dailies. Bolshevik, for instance, sets its circulation at 550,000 copies; Ogonyok at 500,000; Krokodil at 300,000 . It is reasonable to assume that the circulation of the most important dailies is several times these figures. Both dailies and journals are very well printed from the technical point of view. Typographical errors seldom occur. Cartoons, always a skillful communication device of the Soviets, are often outstanding. But here, too, fear of possible misunderstanding is ap- 


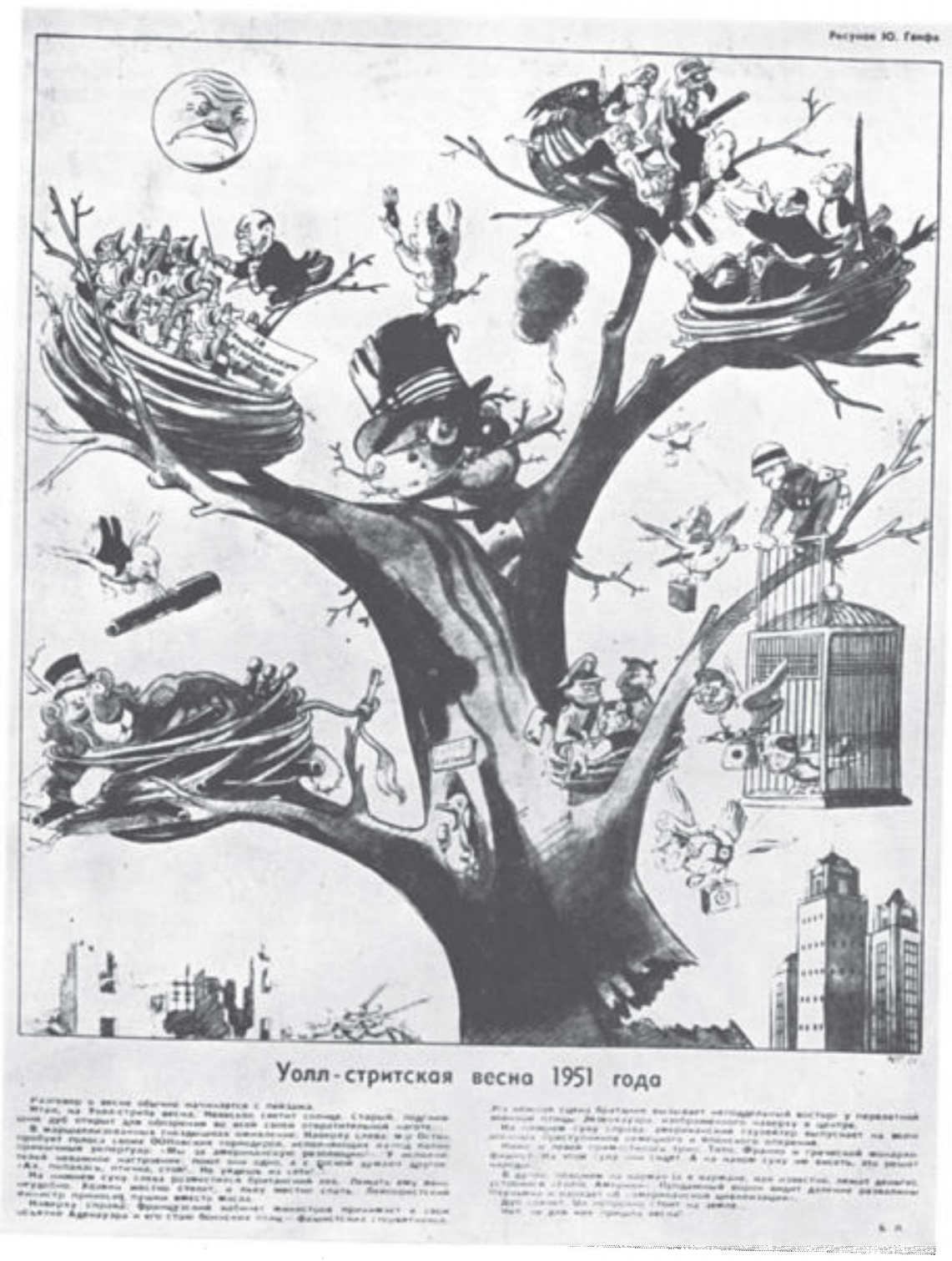

CARTOON IN Ogonyok, APRIL 29, I 95 I 
parent: the drawings are inevitably accompanied by a detailed interpretation of their meaning.

Any topic, animal, vegetable, or mineral, any private thought or desire is bound to serve its turn in the political struggle for man's mind. The Soviet caricaturist "finds tongues in trees, books in the running brooks, sermons in stones. ..." Just a year ago, Y. Ganfa offered in a cartoon "Spring in Wall Street $195 \mathrm{I}$," his interpretation of the season in America. The text reads:

Speaking of spring, you usually start with the scenery.

Well, there is spring time in Wall Street. The sun does not smile. The old, rotten oak tree is wide open for public inspection and can be observed in all its repugnant nakedness.

The marshallized nests are stirring with life. Upper left: Mr. Austin is rehearsing the choir of his bawlers from the UN who are intimidated by his stick into yelling the familiar refrain: "We are in favor of the American resolution!" The cast is not happy about it; they have to sing one thing, and are thinking of quite another: "Little birdie has been caught, can no more escape. . ..."*

The British Lion has been accommodated on the lower branch to the left. It is quite obvious that he does not feel comfortable. The boss made the bed hard, and the lion has a hard time resting. A Laborite cabinet member is seen bringing guns instead of butter.

Upper right: The French Cabinet is welcoming Adenauer and his flock of Bonn's birds of prey-Fascist vultures. This tender scene of fraternization is greeted with unbridled enthusiasm by the military migratory bird Eisenhower who can be seen in the upper center of the picture.

On the lower right branch: An American Gauleiter is freeing war criminals of German and Japanese plumage.

Down to the left a trio has found its place: Tito, Franco, and a Greek monarcho-fascist. They are sitting pretty on this branch. But on what branch they will be hanged will be up to the people to decide.

In a hole in the tree which resembles a pocket (and it is well known that money is kept in a pocket), the "Voice of America" has installed itself. A venal raven, looking at the far-away ruins of Pyongyang, is croaking about "American civilization."

The oak tree is drying up. Cracked at the base, it stands precariously on the ground.

Oh no! Spring has not come for those people!

* Words taken from a popular Russian children's song. 